\title{
The Relationship of Leadership Quality to the Political Presence of Civic Associations
}

\section{Citation}

Han, Hahrie, Kenneth T. Andrews, Marshall Ganz, Matthew Baggetta, and Chaeyoon Lim. 2011. The Relationship of Leadership Quality to the Political Presence of Civic Associations. Perspectives on Politics 9(1): 45-59

\section{Published Version}

http://dx.doi.org/doi:10.1017/S1537592710004081

\section{Permanent link}

http://nrs.harvard.edu/urn-3:HUL.InstRepos:8065967

\section{Terms of Use}

This article was downloaded from Harvard University's DASH repository, and is made available under the terms and conditions applicable to Other Posted Material, as set forth at http:// nrs.harvard.edu/urn-3:HUL.InstRepos:dash.current.terms-of-use\#LAA

\section{Share Your Story}

The Harvard community has made this article openly available.

Please share how this access benefits you. Submit a story.

\section{Accessibility}




\title{
The Relationship of Leadership Quality to the Political Presence of Civic Associations
}

\author{
Hahrie Han, Kenneth T. Andrews, Marshall Ganz, Matthew Baggetta, and Chaeyoon Lim
}

\begin{abstract}
Member-based civic associations, or citizen groups, have two crucial roles in American democracy. They advocate for members' interests in the public arena, but also operate as Tocquevillian "schools of democracy" linking citizens to politics and equipping them with the skills of democratic citizenship. Yet scant research has examined the interrelationships of these two roles. Does the work that civic associations do in developing democratic participants enhance the work they do advocating for members' interests in the public arena? We bring together two previously disparate strands of research on civic associations by arguing that a key factor affecting the political presence of civic associations is leadership quality. We focus on the relationship of leadership quality to political presence, using data from a unique 2003 study of 226 local entities of the Sierra Club. We show that organizations with more skilled and committed leaders have higher levels of political presence. This contrasts with previous research that has focused primarily on community context and resources as explanatory factors. This study shows that political presence is related to the extent to which leaders develop their skills and demonstrate commitment to the organization.
\end{abstract}

7 he study of civic associations, defined here as membership-based advocacy groups governed by internally elected leaders, has burgeoned since the 1990s. A renewed interest in the relationship between civic associations and democracy has emerged among scholars from a variety of disciplines and research areas, including political science, sociology, democratic theory, and civic engagement. ${ }^{1}$ As Archon Fung writes in a review of research on associations and democracy, "By asking the general question, 'How do associations enhance democracy?' scholars have brought civil society and groups back into the normative and empirical investigation of democracy." 2 Scholars have examined the role civic associations play in

A list of permanent links to supplementary materials provided by the authors precedes the reference section.

\section{Hahrie Han is the Sidney R. Knafel Assistant Professor of Political Science at Wellesley College and a Robert Wood Johnson Scholar in Health Policy for 2009-2011 (hhan@rwj. harvard.edu). Kenneth T. Andrews is an Associate Professor of Sociology at the University of North Carolina at Chapel Hill(kta@unc.edu). Marshall Ganz is a Lecturer in Public Pol- icy at the Kennedy School of Government, Harvard Univer- sity(Marshall_ganz@ksg.harvard.edu). Matthew Baggetta is an Assistant Professor in the School of Public and Environ- mentalAffairs at IndianaUniversity (baggettm@indiana.edu). Chaeyoon Lim is an Assistant Professor of Sociology at the University of Wisconsin at Madison (clim@ssc.wisc.edu).}

developing and sustaining democracy in a range of different ways, including incorporating marginalized groups and individuals into the political system; ${ }^{3}$ acting as representative bodies providing many types of individuals a voice in the larger political system; ${ }^{4}$ creating spaces for citizens to develop and practice civic skills while addressing pressing community issues; ${ }^{5}$ providing forums for public deliberation; ${ }^{6}$ and pushing other political institutions towards incorporating values and practices of direct participation. ${ }^{7}$ In the study of social movements, scholars have begun examining the political consequences of protest and specifying the role of leadership, strategy, and organizations for movement impact. ${ }^{8}$ Underlying all of this research is the notion that civic associations are critical to democracy because they provide a way for individuals to participate in informal and formal mechanisms of policymaking.

By creating venues for participation in policymaking, civic associations provide individuals with a way to exercise voice in politics. Only limited research, however, has examined the factors affecting which associations are better able to provide their members with voice than others. Recently, scholars of political incorporation have begun calling for more attention to the ways in which some civic associations are better able to achieve political presence or public recognition than others because they recognize the connection between these associations and the power marginalized groups achieve in politics. Karthick Ramakrishnan and Irene Bloemraad, for instance, find that civic participation by immigrants can lead to greater "political presence." "Political presence" is a term Ramakrishnan 
and Bloemraad use to refer to the extent to which civic organizations "have visibility in their communities and have an impact on other civic and political actors." ${ }^{10}$ Civic associations that have more political presence are better able to provide their constituents with greater voice because they have a seat at the policymaking table. Although this work finds that individuals involved in civic associations achieve greater political presence than those who are not involved, it does not examine why some advocacy groups are able to achieve greater presence than others. ${ }^{11}$

The question of why some associations are better than others at achieving political presence brings research on associations as purveyors of democracy together with research on associations as advocacy groups. Although some research examines how civic associations build democracy by creating institutional forms through which democracy is learned, communicated, and sustained, a parallel body of research examines civic associations as advocacy groups, pushing to enact their agenda into policy. These scholars work primarily within the study of interest groups and social movements and tend to study civic associations in conjunction with a range of other organizations whose primary purpose is influencing legislative outcomes through lobbying and other activities. ${ }^{12}$ In studying the differential success of civic associations in the public arena, these arguments have thus emphasized explanatory factors particularly relevant to the lobbying environment, such as resources, the political environment, or the political opportunities. ${ }^{13}$ These studies essentially "black-box" the internal workings of these organizations and focus instead on the organization's aggregate resources (how much money it has or how many members it claims) or factors external to the organization (characteristics of the environment in which it works). In doing so, they ignore the potential relationship between the work that civic associations do in creating forums for citizens to participate in democracy and the association's ability to provide its members with voice in the political system (the accomplishment of political presence).

We open the "black box" of these associations and contend that an emphasis on resources and political context is incomplete. The ability of a civic association to achieve political presence depends on the quality of its leaders. Within the context of civic associations, leaders must be able to mobilize common effort; in other words, leaders must be able to enable others to achieve purpose, not just pursue individual preferences. ${ }^{14}$ Mobilizing others for action thus requires a distinct set of motivational, relational, and strategic competencies. We focus on two aspects of leadership quality: the extent to which leaders are committed to their work and have the necessary motivational, strategic, and relational skills. This argument builds on research showing that civic associations play an important role in developing the civic skills of citizens and generating social capital, ${ }^{15}$ and research showing that civic leaders have found innovative ways of creating spaces within which this democratic capacity-building can occur. ${ }^{16}$ The argument also bridges across disciplines to apply insights from organizational studies to the political context. Interdisciplinary work in organizational studies has examined the importance of leadership quality in firms ${ }^{17}$ and movement organizations. ${ }^{18}$ This literature recognizes leaders as being central agents of organizational development and performance, influencing not only how effective the organization is, but also the kinds of values the organization embodies and the meanings it represents for individuals who belong to it. ${ }^{19}$ As such, scholars in organizational studies have examined multiple dimensions of leadership that are relevant to organizational performance, including the skill of leaders, their motivations, the way they are structured to do their work, and the kinds of training they receive. We borrow insights from this literature to specify the dimensions of leadership that are most relevant to the effectiveness of civic associations in the political arena.

To study the relationship between leadership quality and the political presence of civic associations, we draw on an original dataset studying the local entities of the Sierra Club, a major national environmental organization. In 2003, we conducted a study, entitled National Purpose, Local Action (NPLA), that collected comprehensive information on the organizational practices and characteristics of over 300 local entities of the Sierra Club. ${ }^{20}$ As a federated, membership-based organization governed by voluntary leadership, the Sierra Club is emblematic of many civic associations in American democracy, particularly those prevalent in American politics since the 1970s (we further discuss the generalizability of findings from our data later in the article). Thus, this study provides a unique opportunity to examine the relationship between political presence and leadership quality in membershipbased civic associations. Our central claim is that the work civic associations do in developing the quality of their leaders informs and supports the work they do in public advocacy — and that without considering leadership quality, we cannot fully understand how some civic associations achieve higher levels of political presence than others.

\section{Understanding the Political Presence of Member-Based Civic Associations}

Since Alexis de Tocqueville's observations in the 1830s, scholars have noted the importance and centrality of civic associations to American political life. Theda Skocpol, Marshall Ganz, and Ziad Munson write, "From churches and unions to social groups and reform crusades, membership associations have provided paths into active citizenship, allowing Americans to build community, pursue shared goals, and influence social and political affairs." ${ }^{21}$ Civic associations underpin democracy by providing venues within which individuals can learn and practice public deliberation, civic leadership, and other skills of democratic citizenship. Tocqueville notes that a key purpose of 
civic associations is to help people realize their broader interests, instead of focusing on their narrow individual preferences. In addition, by employing these venues, they implicitly challenge other public institutions to incorporate deliberation and public participation in governance. ${ }^{22}$ They also play a representative role in policymaking. Although member-based civic associations are only a small proportion of the total number of advocacy organizations operating in Washington, Jeffrey Berry argues that they are particularly important because "for millions of Americans, these organizations are the means by which they support advocacy on the political issues they care the most about." 23 Typically, civic associations are the major organizational legacy and carry forward the traditions and ideals of broad social movements. ${ }^{24}$ Civic associations advocate for their members' interests in the public sphere, and also provide individuals with a way to connect to and identify with the political system, form bonds of social capital, and develop crucial skills for civic participation. ${ }^{25}$

These civic functions render member-based civic associations distinct from other advocacy organizations, which focus primarily on lobbying. Many advocacy groups, such as the Chamber of Commerce, or the Automobile Manufacturer's Association, act as representatives of firms, business groups, or other organizations, instead of drawing their membership from individuals. Research shows that the focus of these interest groups is to lobby government on behalf of its member organizations, not to infuse its organizations with democratic values or to build democratic capacity among individuals who belong to them. ${ }^{26}$

Despite the unique role of member-based civic associations in American political life, most studies of their effectiveness have analyzed them together with other advocacy organizations and interest groups. As a result, most explanations for why some civic associations are more successful in the public arena than others focus on characteristics of the lobbying environment, which are shared by all types of advocacy organizations. The two main explanatory factors that have emerged are the resources the group has and the environmental context within which the group is working. Perhaps the leading explanation for public success among interest groups focuses on the extent to which these groups can act as a source of information and money for legislators. ${ }^{27}$ These studies argue that success depends primarily on how many resources, in terms of money or people, an organized interest has. Groups that can provide votes, money, and information about what voters want have the most influence over re-election minded legislators. As a result, studies of the power of PACs or the electoral activity of interest groups generally operationalize the strength of an interest group as the amount of money it is able to provide a legislator, the number of members it claims in a particular geographic area, or its capacity for mobilizing members for action. ${ }^{28}$ Other research argues that the success of organized interests depends primarily on external, environmental factors. These scholars argue that favorable or unfavorable environmental conditions such as the availability of allies, the strength of opponents, the availability of resources, and opportunities that may exist explain patterns of organizational effectiveness. This research has focused primarily on the context within which the group operates, and the relationships it has to key players. This includes studies of policy subsystems and iron triangles, ${ }^{29}$ studies of direct congressional lobbying, ${ }^{30}$ and case studies of particular policy domains. ${ }^{31}$

In studying the political effectiveness of member-based civic associations, however, we should not ignore their unique characteristics. Insofar as a primary role of civic associations is to teach civic skills, build community, and impart the practices of democratic citizenship to its members, the work civic associations do internal to the organization is as important as the work they do externally, advocating for members' interests. The question that arises, then, is whether the work that civic associations do in developing democratic leadership skills of participants relates to and supports the work they do advocating for members' interests in the public arena. In other words, are civic associations that do a better job as Tocquevillian "schools of democracy" also more likely to be more effective in the political arena? Answering this question links to the literature examining the role that associations play in building democracy, and also fills a gap in the broader literature on interest group effectiveness. Although previous research has shown that interest groups depend on resources to achieve political success, we lack a sense of how these groups translate resources or a favorable political environment into political success.

We propose a new set of independent variables to examine the relationship between leadership quality and the political presence of civic associations. What explains variation in how effectively an organization capitalizes on available resources or political opportunities? Many classic theoretical formulations of organizational behavior highlight leadership quality as a key explanatory factor, but those insights have not been grounded in ongoing empirical work on civic associations. ${ }^{32}$ The logic behind this assertion about leadership quality is straightforward: because civic associations are often self-governing entities whose leadership operates with relatively high autonomy, the success of the organization depends not only on an organization's context and resources, but also on the ability of organizational leaders to effectively engage those resources..$^{33}$ It stands to reason, then, that certain characteristics of the leadership—such as their relational, strategic, and managerial skills, and their level of commitment to their work-should make it more or less likely that they will have the capacity to effectively turn resources and context into public success. Yet we have had few empirical studies of the relationship between leadership quality and the public success of civic associations. Whereas most previous research has essentially black-boxed the organization, we open it up for analysis. 
Our measure of public success focuses particularly on political presence, drawing on Ramakrishnan and Bloemraad's work developing political presence as a measure of effectiveness in civic organizations. They argue that "civic and political presence are important measures of standing, showing the degree to which [organizations] are recognized as full partners in their communities. Civic and political presence are also important precursors to influence in a community." ${ }^{34}$ Specifically, Ramakrishnan and Bloemraad examine the extent to which immigrant communities have a voice at the table. Defined in this way, political presence assesses the degree to which the organization has the standing it needs to be an effective advocate for its constituents. Focusing on political presence is consistent with previous research examining access as an indicator of success. Studies examining access focus primarily on legislative lobbying and argue that access to legislators is a key indicator and correlate of influence. ${ }^{35}$ Yet, advocacy groups work not only in legislative arenas, but also in the courts, the media, and in setting the public agenda. ${ }^{36}$ Securing political presence in these arenas as a spokesperson for policy is a key objective of advocacy organizations, and parallels the idea of securing access to lawmakers. ${ }^{37}$ Examining political presence as an indicator of public success thus allows us to look across multiple arenas of public advocacy that may be particularly important for understanding local civic associations. This is because some associations do not work in legislative arenas but may achieve success by becoming respected sources for information and analysis in public debate and by being seen as authoritative advocates by political elites. Political presence may be conferred by the news media, allies, opponents, elected officials, or government agencies. Civic associations that secure favorable political presence from decision-makers and achieve standing may not prevail in every battle, but their standing gives them much better chances than their peers who lack political presence.

One likely reason that previous research has not explored the relationship of internal organizational factors, like leadership quality, to political presence is the difficulty of obtaining the necessary data. Understanding the effect of leadership necessitates an in-depth look at the internal operations of the organization that is often hard to access, and an ability to examine organizational data that allows us to quantify constructs like leadership quality. To further explicate our approach, we draw on a unique new study of multiple organizations within the Sierra Club. Before going into greater depth on our analyses, we describe the data and the study, National Purpose, Local Action (NPLA).

\section{A Study of the Sierra Club: National Purpose, Local Action}

The National Purpose, Local Action study examines the local organizational units of the Sierra Club, a leading US national environmental organization. Some previous stud- ies of interest groups have examined a sample of organizations working in a wide range of different contexts and issue areas. ${ }^{38}$ These studies have been challenged by the question of how to compare organizational units working in such different issue environments. ${ }^{39}$ Because the Sierra Club is a federated organization, we can study local civic associations working within a common national framework. This allows us to hold organizational context and the broad purposes of the organization constant to assess the impact of leadership development practices alongside rival explanations. It is important to note, however, that the local Sierra Club groups operate with considerable autonomy from the national organization, setting their own agenda and priorities. Thus, there is true variation in the work they choose to do and how they choose to do it.

The Sierra Club is also an excellent organization to study because it is exemplary of contemporary civic associations in several ways. First, it embodies all three characteristics that distinguish civic associations from other organizations: voluntary membership, governance by elected leaders, and the pursuit of voice in the public arena. In 2003, the organization consisted of 750,000 members divided into 343 local groups based on their area of residence. Each local group was affiliated with one of 63 chapters, which roughly corresponded to a state-level organization. Each local group was governed by an Executive Committee composed of leaders elected by mail-in ballots sent to members residing in the group's jurisdiction. None of the local groups in the Sierra Club had any paid staff, and only 23 chapters had more than two paid staff (most chapters only have 1 or 2 paid staff). Each local group was thus a distinct self-governing entity with its own set of elected leaders that conducted its own affairs. Second, as a federated organization, the Sierra Club is part of a tradition of multi-tiered organizations in America that have been of particular interest to scholars because of their potential to combine local action in a national framework. ${ }^{40}$ The Sierra Club, the National Rifle Association (NRA), Common Cause, Mothers Against Drunk Driving (MADD), the Christian Coalition, the National Organization of Women (NOW), and many trade unions are examples of such civic associations that have been the subject of academic study for their advocacy role in American politics. ${ }^{41}$ Third, as a major player in environmental politics, the Sierra Club is part of a movement that scholars often regard as an exemplar of contemporary social movements. Scholarship on the post-1960s advocacy explosion has traced the growth in organizations that rely on direct recruitment of members, that are highly professionalized, advocate on behalf of middle-class constituencies, and employ routine or non-disruptive tactics. ${ }^{42}$ These trends are not limited to the US and mirror key cross-national and transnational developments in the characteristics of advocacy. ${ }^{43}$ Environmentalism shares these characteristics with many modern social movements such as feminism, the consumer rights movement, and the religious right. ${ }^{44}$ 
While the Sierra Club as a whole is an interesting representative of contemporary movements, the analytic leverage and generalizability of the study comes from the study's multi-organization design. Sierra Club chapters and groups are locally-based, self-governing, membership-based organizations that seek voice in the political process. The results of this article could generalize to civic associations that share these characteristics, as they all face the same challenges of developing leadership capable of carrying out program activities in their communities. Our findings are particularly relevant for organizations that operate as federated, national associations. ${ }^{45}$ Although caution should be exercised in extending the findings to organizations not embedded in national federations, this study can be applicable to other state and local civic associations that face similar challenges in gaining political presence.

\section{Data Collection}

The unit of analysis in this study is the local Sierra Club entity with a particular focus on the elected Executive Committee. All of the Sierra Club's US entities were included in the study, except for those that were in reorganization in September 2003. ${ }^{46}$ Our study focused on the local groups and chapters of the Sierra Club, and data was gathered primarily from the members of the local Executive Committees. Our data is based on (1) interviews with Executive Committee chairs (89.9 percent response rate); (2) written surveys with Executive Committee members (51 percent response rate) aggregated to the entity; (3) secondary data available from the Sierra Club on member characteristics, resources, and staff; and (4) secondary data on the organization's community context. ${ }^{47}$ We have full data on 226 entities (178 groups and 48 chapters, or 55 percent of all entities of the Sierra Club).

\section{Variables and Measures}

The objective in our analysis is to examine the relationship between leadership quality and the political presence of civic associations, controlling for the effect of community context and organizational resources. We specifically examine variation in local Sierra Club entities, which work in a common issue environment, but vary greatly in the kind of work they do and the outcomes they achieve. Below is a discussion of how we measure our variables.

\section{Political Presence}

The key dependent variable in this analysis is the political presence of Sierra Club entities. Because consistent objective indicators of political presence are notoriously hard to find, ${ }^{48}$ we develop three different measures-one is a selfreport measure, the second is a measure of local fundraising success derived from budget reports, and the third is a measure of media mentions taken from searches of online newspaper databases. These measures come from three distinct, independent data streams. One is collected from the leaders themselves (a self-report), one is collected from the national organization (budgetary data), and one is collected from sources external to the Sierra Club (media mentions). The independence of the data streams allows us to examine the robustness of our findings across multiple measures of political presence. None of these measures is perfect, and they differ in terms of their strengths and weaknesses. Thus, we perform all of our analyses using all three measures of the dependent variable.

The first measure of political presence is based on the Executive Committee chair's perception of the entity's presence in the community. The chair is uniquely positioned to evaluate the formal and informal mechanisms through which other actors seek out a group's participation and input. In other words, do key actors pay attention to the civic association, its leaders, and its claims? We measure political presence based on responses to six questions from our interview with Executive Committee chairs. Executive Committee chairs evaluated how accurately a series of statements described their group, where 1 indicated "not very accurate" and 5 is "very accurate." The summary scale takes the mean of all six items (Cronbach's alpha = 0.8 ; for this and all other variables, see Table 1 for summary statistics and Appendix A for scale items). This measure has the advantage of being comparable across all of the local Sierra Club entities, regardless of the stage in the policy-making process or the institutional arena the local organization seeks to affect. Because this is a self-report measure, however, questions arise about whether or not it is biased. Prior studies using self-report and independent measures suggest that some of the concern about selfreport measures may be overstated. Scholars have consistently found positive and significant correlations between informant reports and independent measures of organizational effectiveness in a variety of empirical settings including unions ${ }^{49}$ public agencies, ${ }^{50}$ work organizations, ${ }^{51}$ nonprofit organizations, ${ }^{52}$ and civic associations. ${ }^{53}$ Nonetheless, a longer discussion and analysis of potential biases in our data can be found in an article published by Andrews, Ganz, Baggetta, Han, and Lim. ${ }^{54}$ As reported there, we find that respondents do not appear to be positively biased, and that the Chair appears to be a trustworthy informant when we assess the Chair's response on other measures of external indicators.

The second measure examines local fundraising success as an indicator of political presence. This measure distinguishes between money the local entity raises itself and money the entity receives from the state or national organization. Within the Sierra Club, membership dues flow directly from individuals to the national organization. In addition, the national organization does a considerable amount of fundraising at the national level from 


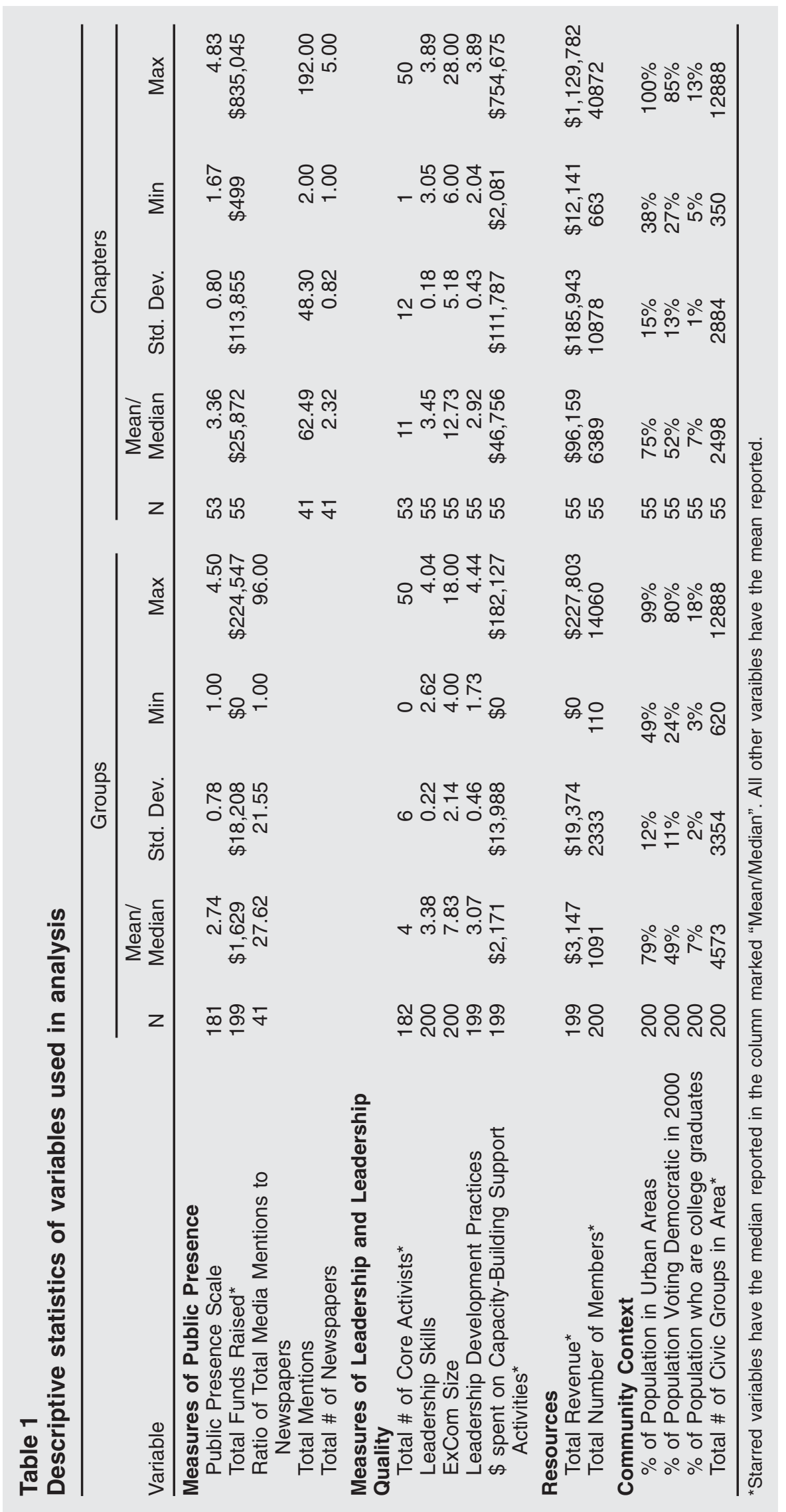


foundations, wealthy donors, and other sources. Most of this money is used to support initiatives of the national Sierra Club, and only a portion of the money goes towards supporting local groups and chapters. The national Sierra Club transfers a portion of the membership dues to chapters, based on a subvention formula. Chapters may then choose how to distribute funds to their local groups. While some chapters distribute a considerable amount of money to their local groups, others distribute none. Thus, almost all local groups have to do some local fundraising to support their operations, often having to raise their entire budget themselves. Local fundraising activities include things like selling calendars, sponsoring lemonade sales, and hosting speakers on environmental issues. Because local fundraising success depends heavily on the reputation of the group in the local community, their fundraising success is an indicator of their level of political presence within the community. Entities with higher levels of political presence should have the reputation, social capital, and networks that enable them to more easily raise funds. These numbers are calculated from annual reports submitted by Sierra Club entities to the national organization for the 2003 fiscal year. Because of the skewed distribution (median $=\$ 2,406$, mean $=$ $\$ 15,483$ ) the measure is logged in analyses.

The third measure examines the number of media mentions each entity receives in the local paper. Media attention is a widely used measure of the visibility and political presence of advocacy groups, ${ }^{55}$ based on the assumption that an entity with more presence will be mentioned more often by local media who consider the organization an important player in local politics and community life. Because of overlapping media markets within the jurisdiction of groups, this measure is only available for chapters whose jurisdiction is an entire state. ${ }^{56}$ Chapters garner more media coverage in general, allowing us to assemble more data for each entity. We began by identifying all the major newspapers in all the major cities that might reasonably cover a particular chapter, namely papers in the chapter's home city, papers in that state's capital city, and papers in other major cities in the state. We then found as many of these papers as possible that included full-text article archives for 2003 in either the Lexis-Nexis or Factiva media search engines. In each paper we searched the 2003 year archives for the terms "Sierra Club" and various combinations of the entity name, the name of the home city, capital city, or major city, and the name of the state. The resulting set of articles was read in full by a trained coder who then coded the article for whether or not it referenced the local Sierra Club entity, or someone affiliated with the local organization. The final measure divides the total number of specific mentions of the local Sierra club entity by the number of newspapers examined in that state (to adjust for the fact that the number of newspapers vary from chapter to chapter).

\section{Correlates of Political Presence}

The key independent variables in our analysis of political presence are measures of leadership. To examine the relationship of leadership to political presence, we build on insights from previous research on leadership and focus on three dimensions of leadership: the quality of the leadership, the size of the leadership team, and the extent to which the organization invests in leadership development and capacity-building activities (such as retreats, training, or community-building social events). The first dimension focuses on quality (do the skills and commitment of leaders relate to the political presence of civic associations?), while the second dimension focuses on quantity (does having more leaders relate to the political presence of civic associations?), and the third dimension examines the extent to which the organization commits time and resources to leadership development within the organization. Although we expect that leadership quality is likely to be most closely related the organization's level of political presence, we examine multiple dimensions of leadership because interdisciplinary research on leadership points to all of these factors as being important. ${ }^{57}$ Our analyses also control for community context and financial and human resources, since those are the factors most commonly thought to explain variation in political presence.

We first assess leadership quality through two measures examining the commitment and skills of leaders. The first measure examines the extent to which leaders are learning civic skills through their work in the Sierra Club. Leaders who are developing better skills should be better able to develop and carry out a broader program of activity that can help the organization achieve political presence. ${ }^{58}$ This scale is based on individual responses to questions on the Executive Committee Leader Survey asking "whether your leadership skills have improved through your service as a volunteer leader in the Sierra Club." The skills included things like "accepting responsibility," "holding others accountable," "organizing and running a meeting," and "managing my time." Respondents were given a fivepoint scale with the two endpoints defined $(1=$ strongly disagree, $5=$ strongly agree). Individual responses were aggregated by taking means at the entity level ${ }^{59}$.

The second measure of leadership quality examines the number of core activists in the organization, because highlycommitted activists often play a critical role in volunteerled organizations. ${ }^{60}$ They conduct much of the motivational, strategic, relational, and administrative work that is necessary for an organization to be operational. Core activists are defined as the individuals who devote five or more hours per week to Sierra Club activity. Thus, we are asking if having more individuals committed to devoting more time to the Sierra Club has an additional relationship to political presence, above and beyond the sheer number of elected leaders that exist. We measure core activists based on a question from our phone interview with the Executive 
Committee chair in which we asked, "How many volunteers spend at least 5 hours per week on Sierra Club work?" 61 We hypothesize that organizations with more committed leaders will be better able to achieve political presence. ${ }^{62}$

In studying the size of the leadership team, we examine the number of members on the elected Executive Committee. We also include this variable as a squared term since previous research on leadership teams indicate that a curvilinear relationship exists. The team needs to be large enough to have enough people to conduct its work, but when it gets too large, its effectiveness decreases as coordination problems increase. ${ }^{63}$ Thus, we expect that leadership teams that are too small or too large will be less effective than those that reach an optimum size in the middle. We should note that while our measure of core activists measures how many committed individuals are actually devoting substantial time to the Sierra Club, our measure of Executive Committee size simply measures how many formal leaders there are (the two measures are only correlated at 0.14 ).

The third dimension of leadership focuses on the extent to which the organization invests in leadership development. Here, we examine two components: first, the extent to which organizations explicitly invest in leadership development, and second, the extent to which they expend resources on activities designed to enhance organizational capacity (these include hosting new members meetings, building leadership through training and retreats, and organizing events to build community solidarity). Organizations that invest in enhancing organizational capacity should be more effective. The leadership development scale is the Executive Committee's average of individual responses to questions on the Executive Committee Leader Survey asking people to agree or disagree with two statements: "Our Executive Committee deliberately tries to identify members with leadership potential," and "Our Executive Committee has clear strategies for bringing new people into leadership positions." Response categories ranged from 1 to 5 with the two endpoints defined ( $5=$ strongly agree). To measure the extent to which entities invest in support activities, we drew on budgetary data they submitted, indicating the level of expenditures that went towards organizational building or support activities. Because the distribution was highly skewed, we logged it. We expect that groups that effectively build internal capacity through explicit leadership development and investment in support activities will be able to achieve higher levels of political presence.

Given previous research focusing on the effect of resources and community context on political presence, we also include those measures in our model. We measure resources using the number of members and amount of revenue an entity has. Members are assigned to groups based on an individual's zip code, and our estimate of membership size is based on data provided by the Sierra Club in August 2003. For regressions in which the dependent variable is the self-report scale of political presence or the media-mentions variable, we also include the total revenue of the organization. ${ }^{64}$ For both measuresmembership size and total revenue-we used the logged measure in the analysis because of the heavy skew in the data. Given previous research on the impact of money and people on public outcomes, ${ }^{65}$ we hypothesize that organizations with more money and more members should achieve greater presence.

Consistent with previous research, we hypothesize that organizations in communities that are more politically friendly will be more likely to achieve higher levels of political presence. ${ }^{66}$ To assess community context, we look specifically at characteristics of the community that are associated with higher levels of environmentalism. Specifically, we examine the percentage of the population within the jurisdiction of the organization living in an urban area, the percentage voting Democratic in the 2000 presidential election, and the percentage of college graduates. We chose these indicators because previous research has found that environmentalism is strongest among highlyeducated, urban, Democratic-leaning communities. ${ }^{67} \mathrm{We}$ also examine the logged number of civic groups in the area, to hold constant the degree to which the Sierra Club competes with other local civic organizations for attention. This data came from the 2000 US Census, Polidata Demographic and Political Guides (www.polidata.org), and the National Center for Charitable Statistics.

\section{Analysis and Results}

For models using the self-report political presence scale (Model 1) or total funds raised (Model 2) as the dependent variable, we use OLS regression. For models using the number of media mentions (Model 3), we use a negative binomial regression, because this model is more appropriate for count data. ${ }^{68}$ The independent variables in the three models are virtually the same, except for the fact that the model using total funds raised as a dependent variable does not include total revenue as an independent variable. In addition, with the exception of the model using media mentions as the dependent variable (which only includes chapters), we included a dummy variable for whether the entity was a group or chapter in our analysis. The results are shown in table 2 .

The key finding emerging from this analysis is that even after controlling for resources and community context, leadership quality consistently has a statistically significant, positive relationship to political presence. Organizations whose leaders report learning skills are likely to have higher levels of political presence, across all three measures of political presence. In models 1 and 2 , the total number of core activists is also statistically significant at $\mathrm{p}<0.05$ and positive (it is not in model 3, but there are only forty cases in that 


\begin{tabular}{|c|c|c|c|c|c|c|}
\hline & \multirow{2}{*}{\multicolumn{2}{|c|}{$\begin{array}{c}\text { Model } 1 \\
\text { Public } \\
\text { Presence Scale }\end{array}$}} & \multicolumn{2}{|c|}{ Model 2} & \multicolumn{2}{|c|}{ Model 3} \\
\hline & & & $\begin{array}{l}\text { Total Fu } \\
\text { Local }\end{array}$ & $\begin{array}{l}\text { s Raised } \\
\text { logged }\end{array}$ & $\begin{array}{l}\text { Ratio o } \\
\text { Mentions }\end{array}$ & $\begin{array}{l}\text { al Media } \\
\text { ewspapers }\end{array}$ \\
\hline & Coef. & Std. Err & Coef. & Std. Err & Coef. & Std. Err \\
\hline $\begin{array}{l}\text { Leadership Quality } \\
\text { Total \# of Core Activists (logged) } \\
\text { Leadership Skills }\end{array}$ & $\begin{array}{l}0.32 \\
0.47\end{array}$ & $\begin{array}{l}(0.10)^{\star *} \\
(0.28) \dagger\end{array}$ & $\begin{array}{l}0.72 \\
1.77\end{array}$ & $\begin{array}{l}(0.25)^{\star *} \\
(0.71)^{\star \star}\end{array}$ & $\begin{array}{r}-0.09 \\
0.60\end{array}$ & $\begin{array}{l}(0.18) \\
(0.28)^{\star \star}\end{array}$ \\
\hline $\begin{array}{l}\text { Leadership Team Size } \\
\text { Executive Committee Size } \\
\text { Executive Committee Size, Squared }\end{array}$ & $\begin{array}{l}0.02 \\
0.00\end{array}$ & $\begin{array}{l}(0.06) \\
(0.00)\end{array}$ & $\begin{array}{r}0.22 \\
-0.01\end{array}$ & $\begin{array}{l}(0.14) \\
(0.01)\end{array}$ & $\begin{array}{l}0.01 \\
0.00\end{array}$ & $\begin{array}{l}(0.08) \\
(0.00)\end{array}$ \\
\hline $\begin{array}{l}\text { Investment in Leadership Development } \\
\text { Leadership Development Practices } \\
\text { \$ spent on Capacity-Building Support } \\
\text { Activities (logged) }\end{array}$ & $\begin{array}{l}0.19 \\
0.12\end{array}$ & $\begin{array}{l}(0.13) \\
(0.09)\end{array}$ & $\begin{array}{r}0.53 \\
-0.04\end{array}$ & $\begin{array}{l}(0.32) \\
(0.23)\end{array}$ & $\begin{array}{r}-0.90 \\
0.37\end{array}$ & $\begin{array}{l}(0.61) \\
(0.39)\end{array}$ \\
\hline $\begin{array}{l}\text { Resources } \\
\text { Total Revenue (logged) } \\
\text { Total \# of Members (logged) }\end{array}$ & $\begin{array}{r}0.02 \\
-0.03\end{array}$ & $\begin{array}{l}(0.03) \\
(0.07)\end{array}$ & 0.45 & $(0.18)^{\star \star}$ & $\begin{array}{l}0.26 \\
0.07\end{array}$ & $\begin{array}{l}(0.24) \\
(0.31)\end{array}$ \\
\hline $\begin{array}{l}\text { Community Context } \\
\% \text { of Population in Urban Areas } \\
\% \text { of Population Voting Democratic in } 2000 \\
\% \text { of Population who are college graduates } \\
\text { Total \# of Civic Groups in Area (logged) }\end{array}$ & $\begin{array}{r}0.39 \\
0.00 \\
5.55 \\
-0.12\end{array}$ & $\begin{array}{l}(0.42) \\
(0.00) \\
(2.32)^{\star \star} \\
(0.08)\end{array}$ & $\begin{array}{r}-0.60 \\
-0.01 \\
0.12 \\
0.03\end{array}$ & $\begin{array}{l}(1.09) \\
(0.01) \\
(5.90) \\
(0.21)\end{array}$ & $\begin{array}{r}1.64 \\
0.03 \\
9.06 \\
-0.24\end{array}$ & $\begin{array}{c}(0.88) \dagger \\
(0.01)^{\star \star} \\
(10.65) \\
(0.29)\end{array}$ \\
\hline $\begin{array}{l}\text { Group ( } 1=\text { Group, } 0=\text { Chapter) } \\
\text { Constant }\end{array}$ & $\begin{array}{l}-0.23 \\
-0.17\end{array}$ & $\begin{array}{l}(0.21) \\
(1.04)\end{array}$ & $\begin{array}{l}-1.17 \\
-4.42\end{array}$ & $\begin{array}{l}(0.51)^{\star *} \\
(2.66)\end{array}$ & -1.89 & $(2.96)$ \\
\hline $\begin{array}{l}N \\
\text { Adjusted R-Squared } \\
\text { Log likelihood ratio }\end{array}$ & $\begin{array}{l}228 \\
0.19\end{array}$ & & $\begin{array}{r}229 \\
0.40\end{array}$ & & $\begin{array}{r}40 \\
0.10 \\
-154.29\end{array}$ & \\
\hline
\end{tabular}

Models 1 and 2 use OLS Regression. Model 3 uses negative binomial regression.

** Significant at $p<.05 ; \dagger$ Significant at $p<0.1$

model, given the need to restrict analysis only to chapters). The magnitude of these effects is also important. An entity at minimum levels of leadership skills is predicted to be 1.2 standard deviations lower on the political presence scale than an entity at maximum levels of leadership skills. ${ }^{69}$ In terms of funds raised locally, the difference between entities at the minimum and maximum level of leadership skills is $\$ 5,371$. Because the variable is logged, it has a curvilinear relationship to political presence. Even so, these differences are large, given that the median of funds raised is $\$ 2,406$. In terms of media mentions, an entity is predicted to more than double its media mentions by moving from minimum levels of leadership skills to maximum levels. Increasing the number of core activists is also related to higher levels of political presence. Moving from no core activists to five core activists (the median) is related to an increase of two-thirds of a standard unit on the political presence scale and about $\$ 1,200$ in funds raised locally. Investing in leadership skills has a slightly larger relationship to political presence than increasing the number of core activists, indicating that it is not only the sheer number of committed activists that matters, but their quality.
Although leadership skills and the number core activists have important relationships to political presence, the relationship between Executive Committee size and investment in capacity-building activities remains unclear. These variables do not achieve conventional levels of statistical significance in any of the three models. It is possible that noise in the data can account for these findings. It is also possible that the number of committed activists matters more than the sheer size of the elected leadership, who may have varying levels of commitment. In addition, it may also be that some entities are investing in leadership development and organizational support activities to no avail-it is only those entities that are actually developing skills in their leaders that witness elevated levels of political presence. Put another way, quality matters when it comes to the relationship of leadership practices and political presence of civic associations.

The effect of community context and resources on political presence is less clear from these models. We cannot reject the null hypothesis that the effect of members and money is zero for Models 1 and 3. For Model 2, which 
examines predictors of funds raised locally, we find that having more members has a statistically significant and positive effect. This may be because entities with more members in their geographic jurisdiction have a broader base from which they can draw to raise funds. It may also be that the number of members in an area is another indicator of the extent to which the area is friendly to the Sierra Club. The community context variables have their most prominent relationship to media mentions. This finding is likely driven by the fact that media mentions are a product not only of the efforts and skills of the local entity, but also the predilection of the local paper to cover the kinds of work local Sierra Club entities may do. Thus, community context has a stronger relationship to media mentions than on the other measures of political presence.

In sum, we find that leadership skills and the number of committed leaders have strong and significant relationships to political presence. This finding is robust to several different measures of political presence and true even when we hold constant the resources an organization has and the characteristics of the community in which it works. Theories of political presence that focus solely on the relationship of external factors like context and resources thus omit an important source of variation in the political presence of civic associations.

Despite the many advantages the data provides in conducting this kind of analysis, there are some important limitations to the study. First, it studies multiple subunits of one larger organization, the Sierra Club. Thus, generalizing these findings to other organizations should be done with caution, although our theory is applicable to other membership-based civic associations. Second, political presence is a slippery concept to assess, and each of our measures of the dependent variables has some flaws. The fact that our findings are robust across multiple measures provides greater confidence in our findings, but future research could strive to develop other objective indicators. Third, the cross-sectional nature of the study is an important limitation. Without longitudinal data on organizational change, it is difficult to make strong causal claims about the relationships between organizational practices and organizational outcomes, particularly given the potentially recursive relationships between some of the variables. We sought to be careful about this throughout the analysis by clearly assessing what constructs the data measured and how those were related to each other. Nonetheless, without comparative statics to examine changing relationships, we must remain cautious about the causal direction of our findings.

\section{Discussion and Conclusions}

By linking individuals to each other in collective political endeavors, civic associations play a unique role in American democracy. They advocate for their members' inter- ests in the public arena and also provide a space in which individuals can cultivate the skills and commitments needed for civic life. This article brings together the study of civic associations as advocacy organizations with the study of civic associations as Tocquevillian schools of democracy. Because previous research has largely separated these two strands of research, it has neglected the study of leadership as a factor related to the public presence of civic associations. Our study finds that the skills and commitment of the association's leaders are related to the political presence of the organization, above and beyond the effect of things like money, members, and politically favorable conditions. The work these organizations do in strengthening democracy by acting as Tocquevillian schools of democracy (their participatory role in American democracy) is also related to their ability to exercise power in the political arena (their advocacy role). Understanding the way these organizations build democratic capacity has implications not only for civic and political participation, but also for our understanding of advocacy power and other public outcomes.

In any democracy, having skilled and committed civic leaders is essential to the durability and impact of associations. As noted at the beginning of the paper, scholars from multiple areas of study have shown a renewed interest in civic associations because of the multiple ways that associations can enhance democracy. They incorporate individuals into the political system by bringing them into association with each other, represent members shared interests in the public arena, advocate for public outcomes, build democratic capacity within the public, and provide public forums within which democratic learning, motivation, and deliberation can be fostered. Leadership is essential to all of this work. Leaders in civic associations push others to find common purpose, and mobilize for action around a shared vision. In some cases, leaders make choices about who to represent and how to represent them, about who gets included and who does not. Leaders determine if and how the organization will deploy its resources, prioritize its goals, and engage with its community to take action. Leaders translate an organization's resources into democratic outcomes (whether they be participatory outcomes like building civic skills in members or reaching out to marginalized constituencies, or advocacy outcomes like advocating for public policy or supporting particular candidates) that the organization values. Achieving any of these outcomes requires that leaders possess a broad array of civic skills. In his work, Ganz identifies "motivational, relational, strategic, and action skills — and the capacity to develop those skills in others" that leaders must have. ${ }^{70}$ These skills are even more essential given the complex policy environments that characterize the work of many modern civic associations. Civic leaders today need relational and strategic skills to work with a diverse range of stakeholders with 
multiple interests, and to know how to adapt to complex policy environments that necessitate a wide range of collaborative and non-collaborative means of making claims on power. ${ }^{71}$ In addition, none of this work comes easily. Leaders have to be motivated and committed to work through the inevitable challenges that arise in any democratic endeavor.

As such, questions about leadership deserve more study from scholars interested in the relationship between associations and democracy. We make a start by demonstrating the relationship between leadership quality and the public presence of civic associations. Yet multiple questions about leadership and leadership quality within civic and political organizations still remain. Descriptively, we still need clearer pictures of the roles that leaders play, the ways that leadership tasks are structured and carried out, and how leaders deliberate in civic associations. Qualitative case studies of high and low performing organizations could provide a strong complement to our quantitative analysis of the relationship between leadership quality and political presence. Through case studies, we could develop a richer understanding of the processes through which leadership capacity is translated into effective political presence for civic associations, and identify the leadership practices that seem to be the most effective. In addition, we lack a clear understanding of how civic associations develop the kinds of leaders they need. What are the processes and practices that are most effective in cultivating committed leaders equipped with the civic skills necessary for democratic leadership? Civic associations serve multiple roles in American democracy, and descriptive and analytic work remains to be done in understanding each of those. Instead of examining each role in isolation from each other, however, we should study them in juxtaposition to each other, to better understand how the participatory functions of civic associations relate to and underpin the advocacy work these organizations do. Only by addressing all of these questions together can we better understand the complex inter-relationships between leadership, associations, and democracy.

\section{Appendix A: Scale Items \\ Political Presence: Scale Items}

- State government leaders consult with us on environmental issues.

- Local government leaders consult with us on environmental issues.

- Officials and public agencies consult with us on environmental issues.

- The local media turns to us as an important spokesperson on environmental issues.

- Our group's activities and positions are covered regularly in the local media.

- Candidates for local office place a high value on our endorsement.

\section{Leadership Skills: Scale Items}

I am better at. . .

- thinking creatively.

- listening to other people.

- accepting responsibility.

- accepting criticism .

- managing my time.

- asking for help.

- asking people to volunteer.

- delegating responsibilities to others.

- coaching and mentoring others.

- providing others with support to do their work well.

- challenging others to be more effective.

- holding others accountable.

- organizing and running a meeting.

- working effectively with public officials.

- working effectively in coalitions.

- speaking in public.

- planning and carrying out a campaign.

- working with the media.

- managing internal conflict .

\section{Notes}

1 E.g., Skocpol and Fiorina 1999; Skocpol 2003; Putnam 2000; Fung 2006; Ramakrishnan and Bloemraad 2008; Boyte 2004; Sirianni and Friedland 2001.

2 Fung 2003, 515.

3 Wong 2006; Ramakrishnan and Bloemraad 2008; Strolovitch 2007; Wohlbrecht and Hero 2005; Rogers 2006.

4 E.g., Wilson 1973; Skocpol 2003; Skocpol, Ganz, and Munson 2000; Berry 1999.

5 Sirianni and Friedland 2001; Boyte 2004; Verba, Schlozman, and Brady 1995.

6 Fishkin 1997; Polletta 2006.

7 Fung 2003.

8 Soule and King 2006; Ganz 2009; Andrews 2001; Amenta et al. 2010; Johnson 2008.

9 Ramakrishnan and Bloemraad 2008.

10 Ibid., 12. In a prior paper (Andrews et al. 2010), we used the term public recognition. Here we adopt the term political presence to be more consistent with prior literature in political science.

11 Ramakrishnan and Bloemraad 2008; Wong 2006.

12 E.g., Truman 1951; Salisbury 1969; Schlozman and Tierney 1986; Walker 1991.

13 E.g., Baumgartner et al.2009; Amenta et al. 2010; Kollman 1998; Andrews and Edwards 2004; Schlozman and Tierney 1986; Smith 1995; Hansen 1991; Laumann and Knoke 1987; Heclo 1978; Bauer, Pool and Dexter 1963; Heinz et al. 1997.

14 Ganz 2010.

15 Skocpol 2003; Putnam 2000; Verba, Schlozman and Brady 1995; Skocpol, Ganz and Munson 2000. 
16 Sirianni and Friedland 2001; Boyte 2004.

17 E.g., Hackman 2002; Nohria and Khurana 2010; Wageman, Hackman, and Lehman 2005.

18 E.g., Ganz 2000.

19 Nohria and Khurana 2010.

20 We draw only on part of the NPLA study. A description of the full study is available at Andrews et al. 2010. That paper examines the effectiveness of Sierra Club groups along three dimensions: political presence (or public recognition), member engagement, and leader development. Here, we focus particularly on the outcome of political presence, drawing on multiple indicators to assess it, and engaging more of the literature in political science.

21 Skocpol, Ganz, and Munson 2000, 527.

22 Fung 2006; Sirianni and Friedland 2001.

23 Berry 1999, 2.

24 Clemens 1997; Minkoff 1995.

25 Putnam 2000; Verba, Schlozman, and Brady 1995; Skocpol 2003; Berry 1999; Skocpol, Ganz, and Munson 2000.

26 Walker 1991; Schlozman and Tierney 1986.

27 Hansen 1991; Smith 1995; Grossman and Helpman 2001; Langbein 1993; Kollman 1998.

28 E.g., Jacobson 1999; Shipan and Lowry 2001; Kollman 1998.

29 Bernstein 1955; Heclo 1978; Lowi 1969.

30 Skocpol 1992; Kalt and Zupan 1984.

31 Bauer, Pool, and Dexter 1963.

32 Wilson 1973; Key 1956; Moe 1980; Burns 1978; Selznick 1957; March and Simon 1958; Thompson 1959; Perrow 1986; Pfeffer and Salancik 1978; Weick 1969; Scott 1998.

33 Ganz 2000, 2009, 2010.

34 Ramakrishnan and Bloemraad 2008, 21-22.

35 Hansen 1991.

36 Burstein, Einwohner, and Hollander 1995; Andrews 2001.

37 Gamson 1990.

38 Walker 1991; Knoke 1990; Schlozman and Tierney 1986.

39 Baumgartner et al. 2009.

40 Skocpol, Ganz, and Munson 2000; Skocpol 2003.

41 E.g., Kenny, McBurnett, and Bordua 2004; Wilcox 2000; Young 2008; Rothenberg 1992; McFarland 1984; McCarthy and Wolfson 1996; Shaiko 1999; Barakso 2004.

42 McCarthy and Zald 1973; Minkoff 1995; Skocpol 2003; Berry 1999.

43 Dalton 1994; Frank, Hironaka and Schofer 2000; Schofer and Fourcade-Gourinchas 2001; Tarrow 2005.

44 Berry 1999; Meyer and Tarrow 1998; Putnam 2000.

45 Skocpol 2003; Skocpol, Ganz, and Munson 2000. Organizations that are run primarily by paid profes- sional staff or that do not have elected leadership do not face the same leadership challenges as organizations that are self-governing and volunteer based.

46 Reorganization status refers to organizations that do not meet minimal standards, such as an elected Executive Committee, and that are receiving assistance from the national organization to reestablish the organization in a community.

47 Details on the data collection procedures are described in greater detail in Andrews et al. 2010.

48 Ramakrishnan and Bloemraad 2008; Baumgartner and Leech 1998; Kalleberg and Moody 1996; Gormley 1982; Herman and Renz 2000.

49 Hammer and Wazeter 1993; Fiorito, Jarley, and Delaney 1995.

50 Gormley 1982.

51 Kalleberg and Moody 1996.

52 Herman and Renz 2000; Herman and Renz 1998; Herman and Renz 2004; Eisinger 2002.

53 Knoke 1990; Knoke 1981.

54 Andrews et al. 2010.

55 Amenta et al. 2009; Andrews and Caren 2010

56 California Chapters were excluded because of the presence of multiple Chapters within the state and the subsequent additional level of organizational structure in California (the Sierra Club California) that made tying a particular media mention to a particular Chapter almost impossible.

57 E.g., Nohria and Khurana 2010.

58 Verba, Schlozman, and Brady 1995; Wageman, Hackman, and Lehman 2005; Hackman 2002.

59 Because this measure focuses on whether respondents report learning skills, as opposed to how skilled they are, there is some complexity in interpreting the measure. Previous research indicates, however, that organizations within which members are learning skills are more likely to have people who are more skilled overall. Thus, we use this as the best data available.

60 McCarthy and Wolfson 1996; Ganz 2000.

61 We tested two different models of the relationship between core activists and political presence and found that the log-linear model $\left(\mathrm{F}_{1,229}=39.43\right)$ better fit the data than the linear model $\left(\mathrm{F}_{1,232}=\right.$ 28.22).

62 Wageman, Hackman, and Lehman 2005.

63 Levine and Moreland 1998; Steiner 1972; Hackman 2002.

64 Because most Group funds are raised locally, we do not include total revenue as a control in the model using local funds raised as a dependent variable.

65 E.g., Hansen 1991.

66 E.g., Walker 1991; Schlozman and Tierney 1986.

67 Barkan 2004; Zukin et al. 2006.

68 Long and Freese 2006. 
69 All predicted values are calculated holding all other variables at their mean (dichotomous variables are held at their mode).

70 Ganz 2010.

71 Sirianni and Friedland 2001.

\section{Supplementary Materials}

Explanatory File

http://journals.cambridge.org/pps2011001

Sample Data

http://journals.cambridge.org/pps2011002

\section{References}

Amenta, Edwin, Neal Caren, Elizabeth Chiarello, and Yang Su. 2010. "The Political Consequences of Social Movements." Annual Review of Sociology 36.

Amenta, Edwin, Neal Caren, Sheera Joy Olasky, and James E. Stobaugh. 2009. "All the Movements Fit to Print: Who, What, When, Where, and Why SMO Families Appeared in the New York Times in the Twentieth Century." American Sociological Review 74.

Andrews, Kenneth T. 2001. "Social Movements and Policy Implementation: The Mississippi Civil Rights Movement and the War on Poverty, 1965-1971." American Sociological Review 66.

Andrews, Kenneth, and Neal Caren. 2010. "Making the News: Movement Organizations, Media Attention, and the Public Agenda." American Sociological Review 75.

Andrews, Kenneth, Marshall Ganz, Matthew Baggetta, Hahrie Han, and Chaeyoon Lim. 2010. "Leadership, Membership, and Voice: Civic Associations That Work." American Journal of Sociology 115 (4).

Andrews, Kenneth T., and Bob Edwards. 2004. "Advocacy Organizations in the U.S. Political Process." Annual Review of Sociology 30.

Barakso, Maryann. 2004. Governing Now: Grassroots Activism In The National Organization For Women. Ithaca, NY: Cornell University Press.

Barkan, Steven E. 2004. "Explaining Public Support for the Environmental Movement: A Civic Voluntarism Model." Social Science Quarterly 85.

Bauer, Raymond A., Ithiel de Sola Pool, and Lewis Anthony Dexter. 1963. American Business and Public Policy. Boston: Massachusetts Institute of Technology.

Baumgartner, Frank, Jeffrey M. Berry, Marie Hojnacki, David C. Kimball, and Beth L. Leech. 2009. Lobbying and Policy Change: Who Wins, Who Loses, and Why. Chicago: University of Chicago Press.

Baumgartner, Frank, and Beth Leech. 1998. Basic Interests. Princeton, NJ: Princeton University Press.

Bernstein, Marver H. 1955. Regulating Business by Independent Commission. Princeton, NJ: Princeton University Press.
Berry, Jeffrey M. 1999. The New Liberalism: The Rising Power of Citizen Groups. Washington, DC: Brookings Institution Press.

Boyte, Harry. 2004. Everyday Politics: Reconnecting Citizens and Public Life. Philadelphia, PA: University of Pennsylvania Press.

Burns, James Macgregor. 1978. Leadership. New York City: Harper and Row.

Burstein, Paul, Rachel L. Einwohner, and Jocelyn A. Holllander. 1995. "The Success of Political Movements: A Bargaining Perspective." In The Politics of Protest, ed. Craig Jenkins and Bert Klandermans. Minneapolis: University of Minnesota Press.

Clemens, Elisabeth. 1997. The People's Lobby. Chicago: University of Chicago Pres.

Dalton, Russell. 1994. The Green Rainbow: Environmental Groups in Western Europe. New Haven, CT: Yale University Press.

Eisinger, Peter. 2002. "Organizational Capacity and Organizational Effectiveness Among Street-Level Food Assistance Programs." Nonprofit and Voluntary Sector Quarterly 31.

Fiorito, Jack, Paul Jarley, and John Thomas Delaney. 1995. "National Union Effectiveness in Organizing: Measures and Influences." Industrial and Labor Relations Review 48 (4).

Fishkin, James S. 1997. The Voice of the People. New Haven: Yale University Press.

Frank, David, Ann Hironaka, and Evan Schofer. 2000. "The Nation State and the Natural Environment over the Twentieth Century." American Sociological Review 65.

Fung, Archon. 2003. "Associations and Democracy: Between Theories, Hopes, and Realities." Annual Review of Sociology 29.

- 2006. Empowered Participation: Reinventing Urban Democracy. Princeton, NJ: Princeton University Press.

Gamson, William A. 1990. The Strategy of Social Protest. Homewood, IL: Dorsey.

Ganz, Marshall. 2000. "Resources and Resourcefulness: Strategic Capacity in the Unionization of California Agriculture, 1959-1966." American Journal of Sociology 105 (4).

- 2009. Why David Sometimes Wins: Leadership, Strategy and the Organization in the California Farm Worker Movement. New York: Oxford University Press. . 2010. "Social Movement Leadership." In Handbook of Leadership Theory and Practice, ed. Nitin Nohria and Rakesh Khurana. Cambridge, MA: Harvard Business School Press.

Gormley, William T. 1982. "Alternative Models of the Regulatory Process: Public Utility Regulation in the States." Western Political Quarterly 35 (3).

Grossman, Gene M., and Elhanan Helpman. 2001. Special Interest Politics. Cambridge: MIT Press. 
Hackman, Richard. 2002. Leading Teams: Setting the State for Great Performances. New York: Harvard Business School.

Hammer, T. E., and D. L. Wazeter. 1993. "Dimensions of Local Union Effectiveness." Industrial and Labor Relations Review 46.

Hansen, John Mark. 1991. Gaining Access, Congress and the Farm Lobby, 1919-1981. Chicago: University of Chicago Press.

Heclo, Hugh. 1978. "Issue Networks and the Executive Establishment." In The New American Political System, ed. Anthony King. Washington, DC: American Enterprise Institute.

Heinz, John P., Edward O. Laumann, Robert L. Nelson, and Robert H. Salisbury. 1997. The Hollow Core: Private Interests in National Policy Making. Cambridge, MA: Harvard University Press.

Herman, Robert D., and David O. Renz. 1998. "Nonprofit Organizational Effectiveness: Contrasts Between Especially Effective and Less Effective Organizations." Nonprofit Management and Leadership 9:23-38.

- 2000. "Board Practices of Especially Effective and Less Effective Local Nonprofit Organizations." American Review of Public Administration 30.

— . 2004. "Doing Things Right: Effectiveness in Local Nonprofit Organizations, A Panel Study." Public Administration Review 64.

Jacobson, Gary C. 1999. "The Effect of the AFL-CIO's 'Voter Education' Campaigns on the 1996 House Elections." Journal of Politics 61 (1).

Johnson, Erik W. 2008. "Social Movement Size, Organizational Diversity and the Making of Federal Law." Social Forces 86.

Kalleberg, Arne L., and James Moody. 1996. "Human Resource Management and Organizational Performance." In Organizations in America, ed. Arne L. Kalleberg, David Knoke, P.V. Marsden, and J.L Spaeth. London: Sage Publications.

Kalt, Joseph P., and Mark A. Zupan. 1984. "Capture and Ideology in the Economic Theory of Politics." American Economic Review 74.

Kenny, Christopher, Michael McBurnett, and David Bordua. 2004. "The Impact of Political Interests in the 1994 and 1996 Congressional Elections: The Role of the National Rifle Association.” British Journal of Political Science 34 (2).

Key, Valdimer O. 1956. Politics, Parties, and Pressure Groups. New York: Thomas Crowell Co.

Knoke, David. 1981. "Commitment and Detachment in Voluntary Associations." American Sociological Review 46 (2).

- 1990. Organizing for Collective Action: The Political Economies of Associations. Hawthorne, NY: Aldine de Gruyter.
Kollman, Kenneth. 1998. Outside Lobbying: Public Opinion and Interest Group Strategies. Princeton, NJ: Princeton University Press.

Langbein, Laura. 1993. "PACs, Lobbies, and Political Conflict:The Case of Gun Control." Public Choice 75.

Laumann, E.O., and David Knoke. 1987. The Organizational State. Madison: University of Wisconsin Press.

Levine, John M., and Richard L. Moreland. 1998. "Small Groups." In The Handbook of Social Psychology, ed. Daniel Gilbert, S. T. Fiske, and G. Lindzey. New York: McGraw-Hill.

Long, J. Scott, and Jeremy Freese. 2006. Regression Models for Categorical Dependent Variables Using STATA. College Station, TX: Stata Press.

Lowi, Theodore. 1969. The End of Liberalism. New York: Norton.

March, James G., and Herbert Alexander Simon. 1958. Organizations. New York: Wiley.

McCarthy, John D., and M. Wolfson. 1996. "Resource Mobilization by Local Social Movement Organizations: Agency, Strategy, and Organization in the Movement Against Drinking and Driving." American Sociological Review 61.

McCarthy, John D., and Mayer N. Zald. 1973. The Trend of Social Movements in America: Professionalization and Resource Mobilization. Morristown, NJ: General Learning Press.

McFarland, Andrew S. 1984. Common Cause: Lobbying in the Public Interest. Chatham, NJ: Chatham House Publishers.

Meyer, David S., and Sidney Tarrow. 1998. The Social Movement Society: Contentious Politics for a New Century. Lanham, MD: Rowman Little Field.

Minkoff, Debra C. 1995. Organizing for Equality: The Evolution of Women's and Racial-Ethnic Organizations in America, 1955-1985. New Brunswick, NJ: Rutgers University Press.

Moe, Terry. 1980. The Organization of Interests: Incentives and the Internal Dynamics of Political Interest Groups. Chicago: University of Chicago Press.

Nohria, Nitin, and Rakesh Khurana, eds. 2010. Handbook of Leadership Theory and Practice. Cambridge, MA: Harvard Business Press.

Perrow, Charles. 1986. Complex Organizations: A Critical Essay. New York: Random House.

Pfeffer, Jeffrey, and Gerald R. Salancik. 1978. The External Control of Organizations: A Resource Dependence Perspective. New York: Harper \& Row.

Polletta, Francesca. 2006. It Was Like a Fever: Storytelling in Protest and Politics. Chicago: University of Chicago Press.

Putnam, Robert. 2000. Bowling Alone: The Collapse and Revival of American Community. New York: Simon and Schuster. 
Ramakrishnan, S. Karthick, and Irene Bloemraad, eds. 2008. Civic Hopes and Political Realities. New York: Russell Sage Foundation.

Rogers, Reuel. 2006. Afro-Caribbean Immigrants and the Politics of Incorporation. New York: Cambridge University Press.

Rothenberg, Lawrence S. 1992. Linking Citizens to Government: Interest Group Politics at Common Cause. New York: Cambridge University Press.

Salisbury, Robert H. 1969. "Interest Representation: The Dominance of Institutions." American Political Science Review 78.

Schlozman, Kay Lehman, and John T. Tierney. 1986. Organized Interests and American Democracy. New York: Harper and Row.

Schofer, Evan, and Marion Fourcade-Gourinchas. 2001. "The Structural Contexts of Civic Engagement: Voluntary Association Membership in Comparative Perspective." American Sociological Review 66.

Scott, W. Richard. 1998. Organizations: Rational, Natural, and Open Systems. Upper Saddle River, NJ: Prentice Hall.

Selznick, Philip. 1957. Leadership in Administration: A Sociological Interpretation. Berkeley: University of California Press.

Shaiko, Ronald. 1999. Voices and Echoes for the Environment: Public Interest Representation in the 1990s and Beyond. New York: Columbia University Press.

Shipan, Charles, and William Lowry. 2001. "Environmental Policy and Party Divergence in Congress." Political Research Quarterly 54 (2).

Sirianni, Carmen, and Lewis Friedland. 2001. Civic Innovation in America: Community Empowerment, Public Policy, and the Movement for Civic Renewal. Berkeley and Los Angeles, CA: University of California Press.

Skocpol, Theda. 1992. Protecting Soldiers and Mothers: The Political Origins of Social Policy in the United States. Cambridge: Harvard University Press.

Skocpol, Theda. 2003. Diminished Democracy: From Membership to Management. Norman, OK: University of Oklahoma Press.

Skocpol, Theda, and Morris P. Fiorina, eds. 1999. Civic engagement in American democracy. Washington, DC: Brookings Institution Press and Russell Sage Foundation.

Skocpol, Theda, Marshall Ganz, and Ziad Munson. 2000. "A Nation of Organizers: The Institutional Origins of Civic Voluntarism in the United States." American Political Science Review 94 (3).

Smith, Richard. 1995. "Interest Group Influence in the U.S. Congress.” Legislative Studies Quarterly 20.
Soule, Sarah A., and Brayden G. King. 2006. "The Stages of the Policy Process and the Equal Rights Amendment, 1972-1982." American Journal of Sociology 111 .

Steiner, Ivan. 1972. Group Process and Productivity. New York: Academic Press.

Strolovitch, Dara. 2007. Affirmative Advocacy: Race, Class, and Gender in Interest Group Politics. Chicago: University of Chicago Press.

Tarrow, Sidney. 2005. The New Transnational Activism. Cambridge: Cambridge University Press.

Thompson, J. 1959. "Strategies, Structures, and Processes of Organizational Decision." In Comparative Studies in Administration, ed. J.D. Thompson. Pittsburgh, PA: University of Pittsburgh Press.

Truman, David B. 1951. The Governmental Process: Political Interests and Public Opinion. New York: Alfred A. Knopf.

Verba, Sidney, Kay Lehman Schlozman, and Henry Brady. 1995. Voice and Equality: Civic Voluntarism in American Politics. Cambridge: Harvard University Press.

Wageman, Ruth, Richard Hackman, and Erin Lehman. 2005. "Team Diagnostic Survey, Development of an Instrument." Journal of Applied Behavioral Science 41 (4).

Walker, Jack L. Jr. 1991. Mobilizing Interest Groups in America: Patrons, Professions, and Social Movements. Ann Arbor: University of Michigan Press.

Weick, Karl E. 1969. The Social Psychology of Organizing. Reading, MA: Addison-Wesley Publishing Co.

Wilcox, Clyde. 2000. Onward Christian Soldiers? The Religious Right in American Politics. Boulder, CO: Westview Press.

Wilson, James Q. 1973. Political Organizations. New York: Basic Books, Inc.

Wohlbrecht, Christina, and Rodney Hero. 2005. The Politics of Democratic Inclusion. Philadelphia: Temple University Press.

Wong, Janelle. 2006. Democracy's Promise: Immigrants and American Civic Institutions. Ann Arbor: University of Michigan Press.

Young, McGee. 2008. "From Conservation to Environment: The Sierra Club and the Organizational Politics of Change." Studies in American Political Development 22 (2).

Zukin, Cliff, Scott Keeter, Molly Andolina, and Krista Jenkins. 2006. A New Engagement? Political Participation, Civic Life, and the Changing American Citizen. New York: Oxford University Press. 